Martin O’Shaughnessy (Nottingham Trent University, UK)

\title{
Eloquent Fragments: French Fiction Film and Globalization
}

\section{$\underline{\text { Abstract }}$}

French (and Franco-Belgian) cinema has witnessed a return to the real since the middle of the 1990s and should thus successfully have pinned down the impact of the globalizing economy on the socio-political sphere. Yet neo-liberal globalization is deeply resistant to representation within the frame of conventional fictions. Condemned to be a cinema of fragments by the shattering of the old leftist imaginary, has French cinema merely tracked globalization's local consequences, always letting systemic causes escape its grasp? Or has it identified successful strategies with which to restore eloquence to social struggle and suffering that otherwise seemed condemned to silence? Engaging with important films by the Dardenne brothers, Robert Guédiguian, Bertrand Tavernier, Manuel Poirier, Matthieu Kassovitz and others, this paper argues the latter. French film, it suggests, has found ways to make the fragments speak to the totality, to short-circuit neo-liberal triumphalism and to interpellate a nation that no longer plays its erstwhile integrational role. While none of these strategies can provide totalizing systemic critique, they do show that cinema is playing an active role in the rebuilding of a radical oppositional imaginary.

\section{$\underline{\text { Key words }}$}

Cinema, globalization, politics, critique, fragments

I will begin this piece with two contradictory observations that I will later try to reconcile. ${ }^{1}$ The first is that neo-liberal globalization is deeply resistant to representation within the 
framework of conventional fiction. The second is that, following its much trumpeted return to the real in the 1990s, French cinema could not avoid figuring the consequences of that same capitalist globalization. Reconciliation of this paradox will lead to the suggestion that French (or rather Franco-Belgian cinema) has above all focused on the fragments left behind once globalization has passed through the social terrain. But, far from producing a satisfactory solution, this reconciliation only opens onto a dilemma. How can a cinema of fragments speak productively of what has happened at the systemic scale? The dilemma, it will be suggested can be addressed in different ways, each with its own effectiveness but also with its limitations which are not intrinsic to cinema but indicative of the broader political lack of an overarching language of opposition.

\section{Defying representation}

I will now explain the first of my two contradictory observations, namely that capitalist globalization defies representation. The suggestion here is that capitalism's ability to deterritorialize and disembody itself, to outsource and subcontract its production, and to distance itself from its social impact, have all made it ever more difficult to locate and pin down. Traditionally told stories focused on individuals in concrete spatial locations are increasingly inadequate to deal with its processes at the systemic level. They are perhaps limited to registering local, embodied conflicts and sufferings whose structural causes they are unable to figure, except through intrusive dialogue, contrived plot mechanisms or heavy symbolism, clumsy but perhaps necessary features to which we will return.

A contrast between two films, one from the immediate aftermath of 1968 and one from the contemporary period, can help illustrate this point. The first film is Godard's celebrated 1972 film Tout va bien which shows how a hitherto tranquil meat processing factory becomes 
contaminated by the spirit of 1968 leading to both the sequestration of the boss and the casting off of the disabling, bureaucratic influence of the communist dominated trade union, the CGT. Events are witnessed by two outsiders, a journalist and film-maker, famously played by Jane Fonda and Yves Montand, who are stimulated to think through their own relationship to the broader struggle. Fonda works for an American broadcaster, while Montand, as a Communist fellow-traveler, has been associated with anti-colonial struggle and has split with the party over the Soviet repression of Czechoslovakia. The Vietnam war, that classic focus of simultaneous international mobilization, continues in the background. Although the film locates itself in a specific place and engages with oppression in its immediate corporeality through attention to noise, smell and physical discomfort, it is also effortlessly systemic in its sweep. It mobilizes institutional and class actors and connects the local, national and international, while asking overarching, strategic questions about the articulation of the personal and the political, about the state of the struggle, and about the role of cultural producers within it.

In contrast, Guédiguian's A l'Attaque (2000) shows the current difficulty of working at a similar systemic level, even when the political fable chosen as a vehicle is firmly derealized by location as a fiction in the frame of a discussion between a film-maker and a script writer. Like Tout va bien, the film recounts a sequestration, this time of the manager of a transnational company by a garage owning family threatened with bankruptcy by the company's refusal to pay its debts. It thus struggles manfully to engineer a melodramatically eloquent face-to-face collision between a residual fragment of the common people and a representative of corporate power, implausibly brought together in the same story space. While Godard's film is an examination of what is possible at a specific historical moment, Guédiguian’s is knowingly impossible wish fulfillment. Its Brechtian framing fails to save it 
from its own absurdity and serves only to underline the difficulty of figuring the dynamics of capitalist globalization within the spatio-temporality of conventional fictions.

\section{Figuring the fragments}

Let us move on now to the second observation. In the 1990s, and notably through the rebirth of a strong social realist strand, French cinema has repeatedly figured social malfunctions whose virulence cannot be understood outside of the context of capitalist globalization, even if one dispenses with the language of economic determination in the first or last instance. This has occurred in a range of ways. Films like Erick Zonca’s La Vie rêvée des anges (1998), the Dardenne brothers’ Rosetta (1999), Laetitia Masson’s En avoir ( ou pas) (1995), Manuel Poirier's Western (1997), Bertrand Tavernier's Ça commence aujourd'hui (1999), and Robert Guédiguian’s Marius et Jeannette (1997) have closely tracked the local, embodied struggles of isolated or vulnerable individuals exposed to the violences of precarious employment or enforced unemployment. They have often done so in old, industrial heartland areas such as Marseille or the North and Northeast and with reference to a now dismantled working class and the institutional actors and universalistic discourses associated with its struggles. The same group of films has also helped to record the micro- geographies and conflicts of contemporary social exclusion. In this they have been abetted by the important cluster of films that focus on the banlieue, the outer city housing estates, or projects, tracing the disaffection and pre-political rebellion of culturally, economically and ethnically marginalized youth and their collisions with an increasingly repressive state. Matthieu Kassovitz's $\mathrm{La}$ Haine (1995) is the best known of this group of films but far from the only significant example. Another related cluster of films, usually known as Beur cinema, record the struggles of young people of ethnic minority origin to find a place for themselves in a world prey to racism and discrimination. Malik Chibane’s Hexagone (1994) and Karim Dridi’s Bye-bye 
(1995) are examples one could cite. A number of films engage with the precarious state of migrants and their extreme vulnerability when caught between ruthless employers and state repression. If the Dardennes' La Promesse (1996) is an early example, the more recent release of Alain Gomis’s L’Afrance (2002), Cheik Doukuré’s Paris selon Moussa (2003), Julie Bertucelli’s Depuis qu’Otar est parti (2003) and François Dupeyron’s Inguelezi (2004) suggest an emergent series.

All the above films focus in one way or another on the local struggles of small groups or individuals, usually with no viable collective, political language to name the wrongs done to them and to articulate them within a universalizing framework whose dimensions might encapsulate and engage with globalized causality. A small number of films portray collective struggles framed within a more conventional politics. The struggles shown are at best defensive and at worst doomed. Laurent Cantet’s fine film Ressources humaines (2000), which represents a small-scale strike against redundancies, is perhaps the best-known example. But one could also cite Florent Emilio Siri’s Une Minute de silence (1998) which shows miners in ferocious confrontation with the police as their industry is shut down, or Dominique Cabrera's Nadia et les hippopotames (2000), which returns to the mass strikes of December 1995 and focuses on the encounter between striking public sector workers and an impoverished single mother as a way of exploring how a broad oppositional front might be rebuilt. $^{2}$

The breadth of the concerns raised in the films mentioned might tempt one to assert that French cinema has successfully mapped capitalist globalization, recording its impact on certain industrial regions and urban zones, tracking its demolition of the old, organized working class, noting its exacerbation of racist exclusions, while tracing its mass production 
of social vulnerability and displacement. A more nuanced assessment, one that effects a provisional reconciliation of my two initially contradictory observations, would be that it has tracked the consequences in their easily identifiable social and spatial locations but neglected causes that were not so easily pinned down and placed on screen. If this were so, a churlish comment might be that social realist films were playing into the hands of the very forces that they might seem to oppose by distracting from the bigger picture and abetting capitalism's ability to distance itself from its effects. A more generous remark might be that it had become difficult, if not impossible, to simultaneously keep in focus, within the frame of fiction, the bigger picture and the diverse, fragmentary sufferings left behind by the forced dismantling of class solidarities and grand narratives of opposition. I will now turn to two Belgian filmmakers, the Dardenne brothers, whose trajectory provides a perfect illustration of the point I am making. The Dardennes have been important figures on the French cinematic landscape since La Promesse (1996) and, more especially, since their triumph at Cannes with Rosetta (1999). Their earlier career is much less well known.

\section{The exemplary trajectory of the Dardenne brothers}

The Dardenne brothers began by making oppositional video film in the 1970s, working in direct collaboration with leftist organizations and producing work for immediate use in the political struggle that so characterized that decade, notably its earlier years. In the later 1970s and early 1980s, their career mutated as they shifted from interventionist militant video to interrogative political documentaries that, entirely in keeping with the demobilization of the moment, asked where the struggle had been and how it might move on. ${ }^{3}$ More specifically, they sought to record, preserve and pass on the collective memory of workers or wartime resisters who had been engaged in epic struggles framed by universal principles and aspirations. Their 1990s work saw a further evolution as they again sought, one might say, to 
remain 'contemporary' with their times. Moving out of their earlier epic mode, they chose to focus instead on individuals left to confront the violences of exploitation and economic exclusion with no memory of previous struggle, no collective solidarities and no pre-existent discourses of opposition to draw upon. Their little known film Je pense à vous (1992) lies at the juncture of these two very different modes of engagement with social struggle, eloquently recording the passage from one to the other and thus helping us to gauge the paradigm shift that was occurring in the mode of appearance of the social.

The first part of Je pense à vous revolves around the fight to keep a steelworks open in the face of global over-production and competition. At this stage, the individual protagonists are tied into a collective struggle played out between unions, politicians and management against the setting of the steel factory, a suitably grandiose location. The workers, manipulators of fire and matter and embodiment of the old Promethean working class, seem of suitable collective proportion to engage in the epic. But the struggle is lost without them seeming to have real potential to resist. As a result, the social being of Fabrice, the main character, collapses and he abandons home and family. We pick him up again, a demoralized wreck, working as part of a laboring gang in the underground economy. He only rediscovers selfrespect when, revolting against the brutal and arbitrary treatment meted out to another worker, he fights hand to hand with the thuggish gang master for whom he performs menial manual labor. He then sits bandaging the hand of the other worker as, at a minimalist, physical level, the basic foundations of social solidarity are restored.

The contrast between the film's two struggles, the first against the factory closure, the second against brute oppression, illustrates the paradigm shift in the mode of appearance of the social towards which I am pointing. Epic in nature, the first struggle had identifiable collective 
actors, possessed a familiar language and symbolism and was politically and institutionally mediated to a national and international frame. The second mode of struggle is corporeal, immediate and local. Having lost any collective voice and deprived of universalizing instances of mediation, it is essentially mute and can thus provide no general account of its origins or of its conditions of existence. What it can do, however, is draw our attention to that which is unacceptable around us and begin to undo its muteness through close attention to embodied suffering and through the melodramatic production of moments of transparency when injustices and ethico-political choices again become apparent and meaningful. ${ }^{4}$ This is precisely what happens in the fight scene in Je pense à vous and more broadly in subsequent Dardenne brothers’ films.

Thus situated at the intersection of two modes of appearance of the social, Je pense à vous might seem able to show both the present state of affairs and its origins, and thus to successfully domesticate neo-liberal globalization at the narrative level. Yet such an analysis would neglect the traumatic narrative dislocation contained within the film, its shift from an epic, collective scope, to a local level that cannot engage with the systemic. Globalization is in fact figured as something that has happened, as a catastrophic yet tellable event that has passed through the social world, creating the scarred terrain upon which smaller more opaque and fragmentary stories may then occur. It is not encapsulated as ongoing process. The Dardennes' subsequent films entrench the transition signaled in Je pense à vous, abandoning an epic historical and explanatory dimension to focus ever more tightly on the embodied social suffering, economic violences and individualized ethico-political choices of the present. $^{5}$ 
Their next film, La Promesse, still allows us to see the massive but now empty buildings, which the organized working class once inhabited. They form a silent backdrop to, and mute explanation of, the small-scale but grim foreground drama. However, the film's main focus is on tracking the intense micro-drama played out between a father and son and the illegal immigrants that they employ. An early sequence showing them bringing the migrant workers into town perfectly illustrates the film's complex and dislocated spatio-temporal frame. For parts of the sequence the characters are filmed from inside the van in which they are traveling, with the camera at times in very close proximity to them, recording and amplifying their gestures and their facial expressions. At other times, the van is filmed in long shot as it traverses a décor of empty factories. Two different stories are thus held in tension. The hollowed out industrial landscape points towards a larger history now only accessible through its physical traces. The tight space of the van suggests an intense micro-drama located in the present but whose explanation must somehow lie outside itself, connected in some way that the film can never develop, and which the depoliticized characters can never voice, to the empty factories and to the presence of a new, internationalized and hyper-exploited set of workers. Causality, one might say, has moved out of story space and time into a before and an elsewhere. Not being able to figure the global as a process, the film must point to that which it cannot show even as it makes it own commitment to accompany and render eloquent the local, social suffering of the characters.

Rosetta takes this commitment a logical step further. It tracks its leading character so closely that the epic, industrial landscape where the drama is still located disappears from view. As the brothers themselves explained, the characters and their micro-dramas would have been dwarfed had they kept it in frame. ${ }^{6}$ The film's action cannot of course be understood outside of the context of neo-liberal triumph, yet, respecting the bounds of the heroine's narrow 
perspective, it refrains from providing any broader explanatory framework. It thus forces us into unbearable proximity with the raw violences of a real whose brutality it opposes through the reinscription of the possibility of personal ethico-political choices. It achieves this through the development of moments of melodramatic transparency when the heroine has to decide just how far she will go to get and keep a job. Will she literally destroy the other - by refusing to save him from drowning, thus claiming his job - or will she choose some form of interdependence? Through this crystallization of a fundamental ethical choice, the film begins to domesticate the brutal consequences of capitalist globalization at the personal and local level but seems to have abandoned the systemic. ${ }^{7}$ However, by showing the potential collapse of the social and its replacement by a Hobbesian fight of all against all, it still manages to give its fragment general relevance. ${ }^{8}$

\section{Between immediate suffering and the memory of struggle}

Collectively, the Dardennes’ films help to illustrate the range of choices available to films engaging with current social disorders. Some films - Zonca’s La Vie rêvée des anges or Masson’s En avoir (ou pas) for example - show characters with no inherited political language or resources acting out dramas of individualized social disarray in a landscape that seemingly bears no memory of earlier struggles. At stake in these films are the very nature and indeed the possibility of social connectivity and of a non-destructive relationship with the Other. That is why, I would suggest, they ask ethico-political questions of us, rather than simply inviting us to share in a voyeuristic and depoliticizing contemplation of the misery of the margins. Other films - such as Tavernier's Ça commence aujourd'hui or Guédiguian’s Marius et Jeannette - bear a memory of the historical defeat of organized labor or locate their small stories within the epic industrial landscape where class struggle once took place. While the former type of film, like Rosetta, derives its effectiveness from the suffocating denial of 
an explanatory frame or an ideological outside, the latter keeps the past in complex relationship with the present, denaturalizing neo-liberalism by reminding us that its current triumph is the result of a struggle, reminding us that struggle was possible and keeping the resources of resistance alive, but also noting the historical defeat of the twentieth century Left.

Both types of film also, of course, seek to make contemporary social suffering visible and eloquent and thus refuse neo-liberal globalization's utopian drive. Lacking, as I have suggested, the frame and language to achieve systemic critique in the present, they might seem to be saying, not 'there is a global alternative' nor 'this doesn't work anywhere,' but simply, yet emphatically, 'this is not working here.' Although the latter kind of intervention might seem to be condemned to ineffectiveness due to its narrow scope and explanatory inadequacy, it can still, by a kind of short-circuiting, attain the universal negatively by connecting to, and making a small puncture in, the global utopian pretensions of triumphant capitalism. The following two examples show how this might work.

\section{Short-circuiting to the universal}

Like Je pense à vous, Kassovitz’s La Haine can usefully be thought of as having a complex and dislocated spatio-temporality. The film has a historical memory. An old Jewish man improbably met in some public toilets recalls Soviet persecution while a torture scene in a police station, involving the black and the beur characters, inevitably evokes France's colonial past. These memories have potential resonances (and lessons) for contemporary exclusions, yet they are ones that characters locked into their present dramas cannot access. The film connects to global spatiality. Most of the characters' cultural references seem to be to the United States, both in the famous scene where Vinz, the Jewish character, imitates De Niro’s famous ‘Are you looking at me?’ scene from Taxi Driver (Scorsese, 1976) and in the 
more sustained influence of hip-hop. Yet, the characters themselves are limited to a much narrower and more contested spatial frame as they move painfully between the banlieue and the center of the capital. Their space-time is much more restricted than that constructed through the film's web of cultural and historical references.

The banlieue itself is both prison and sanctuary, a site where the young men experience their social marginalization, struggle for control of public and open spaces and seek to inscribe their presence through music, dance, tags and graffiti. The capital is experienced as a place of both cultural exclusion and police harassment, a hostile place that they struggle both to enter and to leave. However, it is during their visit there that the short-circuiting to which I am referring is most obviously signaled in what might seem a contrived moment with intrusive symbolism of the sort mentioned in the introduction to this piece. The young men are walking in the nocturnal streets. Imitating a sequence from the film Un Monde sans pitié (Rochant, 1989), they try but fail to give the impression of turning out the Eiffel tower, as the hero of the earlier film had done, by clicking their fingers at the time when the tower is usually switched off. This failure encapsulates their inability to establish themselves in their nation's center, a point to which we will later return. As they walk away, Saïd, the beur character, stops by something that his two companions, absorbed in argument, seem not to notice. It is a large advertising hoarding with a poster picturing the globe and a caption 'le Monde est à vous'. Connecting to a different spatial frame, the poster gives what might seem a purely local drama a new resonance. The young men's painful and repeatedly constricted mobility clearly gives the lie to the utopian promise of a poster that offers access to the globe as commodified space. But the film does not leave things there. Saïd modifies the poster’s caption, crossing out the ' $v$ ' of 'vous' and replacing it with an 'n' so that it now reads 'le monde est à nous'. Though superficially tiny, the change is profoundly significant. It suggests a simultaneous 
refusal of the poster's consumerist interpellation and a minimalist but resonant re-inscription of a political subjectivity that, having no universalizing language to oppose to the current order, can only lay claim to the universal by appropriation of the code of the dominant.

A similar short-circuit to the global occurs in Tavernier's Ça commence aujourd'hui, a film which centers on the heroic struggle of the head-teacher of a primary school in a northern town once built around the mining industry but now subject to deep social decay. Early in the film, a politician delivers a speech saying that Germinal is finished, that protectionism is a blind alley, and that the area must change its image and embrace tourism and the laws of the market. As he finishes, he is stopped by a social worker who complains that they have lost two posts, a nursery teacher and a psychologist, that they can ill spare. The politician replies with statistics, proudly boasting that their provision is $93 \%$ of the national average. The social worker replies that these figures mean nothing 'sur le terrain'. Two levels of discourse thus meet in a transparently engineered but eloquent collision. One is drawn from the currently dominant language of global competitiveness, the other rooted in the local and the immediate. While, the latter can only appeal to pressing need and suffering and not to any overarching principle, it can, as I have suggested, reach the universal negatively, by disrupting the confident claims of the former and simply saying, 'this does not work here'. It also does something more, as we shall shortly see, by interpellating the nation and reminding it of its role.

\section{Interpellating the national}

During the modern era, the nation has been the privileged mediating instance between the individual and the universal, at both a symbolic and a material level. In the current era of globalizing capital, it no longer seems willing or able to play this role. Etienne Balibar 
provides illuminating commentary on the symbolic dimension of this shift in his recent work, La Crainte des masses. Drawing on Hegel, he notes how, at the birth of the modern period, the nation simultaneously dis-embedded and re-embedded individual belonging through the enforced subjugation of all particularisms to the universalizing instance of the national. In practice, this meant that while one could still retain local identifications, these were only licit to the extent that they became manifestations of the nation. In recent decades, Balibar notes, economic globalization has brought about a further enforced dis-embedding of individuals, but this time without the crucial, compensatory re-embedding that the nation once provided. ${ }^{9}$ One might complement his analysis on the material level by noting how, in the twentieth century, as economic processes became increasingly trans-national, the nation developed an expanding series of protections, culminating in the post-1945 development of the welfare state. In recent decades however, the expansion of trans-national economic connectedness, has been accompanied by the weakening of national protections. Nations have thus become decreasingly able or willing to play their erstwhile integrative and protective role on either the symbolic or the material level. As some of the films that we have considered eloquently illustrate, globalising economic forces now increasingly collide with the individualized and localized resistances of those deprived of either the symbolic or the material resources to deal with them adequately.

Cinema can, as we have noted, seek to restore eloquence to these often mute resistances or short-circuit neo-liberalism's utopian and universalizing drives. But it can also interpellate the failing mediating instance, the nation, reminding it of its responsibility to preserve a cohesive national society. Just such an interpellation can be found in La Haine and Ça commence aujourd'hui as well as in a film we have yet to discuss, Manuel Poirier’s Marion (1995). 
It is surely no accident that the young men in La Haine are not simply shown in the banlieue but are sent into their nation's social, cultural and economic center. Their disastrous journey does not simply show a geographically circumscribed exclusion - although it does that eloquently enough - but also sends a message to the nation. This point, one which underlies the whole film, is already present in the pre-title sequence when a petrol bomb is seen crashing into a globe while a voice begins to recount, 'c'est l'histoire d’une société qui tombe'. When the national society ceases to provide cohesion and meaningful connectivity to a larger unit, what remains is the brute collision of global forces and local resistance (the petrol bomb).

Much less apocalyptic than La Haine, Poirier’s Marion also points to the nation’s failure to integrate. The film foregrounds the plight of one family that struggles to make ends meet and provide a future for its children. As we see in its opening schoolroom scene, one strand of public service, the education system, still seems to represent the values of Republican integration and civic solidarity. Subsequent developments complicate matters, however, by underlining the advantages bestowed upon the privileged few in the nation's heart by their access to the best Parisian lycées. Another public service, the EDF (Electricité de France), seems to have adopted a narrowly commercial role, being happy to publicly humiliate the central family by publishing their names for having tampered with their meter. Meanwhile, as an early sequence shows, local residents are obliged to mobilize to prevent the closure of their local train service and their consequent detachment from the national network. By this orchestration of sequences involving erstwhile agencies of national connectivity, the film underlines the withdrawal of the state from its public role while at the same time using the school to remind us of what that role used to be. 
Along some similar lines, Ça commence aujourd'hui also interpellates the national as failing mediating instance. Firstly, as we have noted, it engineers collisions between spokespeople for the misery it portrays and official representatives of the Republic in the shape of the politician already discussed, a local communist mayor and a school inspector. Secondly, it stages its action in that core place of Republican integration, the state primary school, and thus once again makes privatized sufferings a public, national concern. Indeed, by thus using the school to assemble a diversity of social problems, it indicates a potential way to resist the extreme social fragmentation that we find in other films.

\section{Gathering the fragments?}

Throughout its course, as we have noted, Ça commence aujourd'hui's pulls together diverse, individuated social sufferings. Moreover, it ends positively with festivities that unite its cast of cultural creators, pupils, teachers and parents, ethnic minorities and white French people. It might thus seem to suggest that public services and the ethic they represent are still able to resist social atomization. Yet the festivity is an end in itself, a utopian interruption of disintegration that, rather than providing a real antidote to it, shows that it is not inevitable. The film's energy is essentially drawn from isolated individuals who heroically resist what happens around them, rather than from a more truly collective dynamic. Thus, it does not in the end suggest that either a cohesive society or a unified working class can still be found. Rather, by holding fragmentation and the desire for solidarity in tension, it expresses its own resistance to atomization.

Something similar lies at the heart of Guédiguian’s La Ville est tranquille (2001), which has a more developed choral structure than Tavernier's film, where everything is still connected through the central protagonist. From its opening sweeping pans of Marseille, Guédiguian’s 
film is marked by its desire to register yet resist fragmentation. The film tracks individual instances of social misery (racism, prostitution, drug abuse) and holds them in tension both with the story of a once powerful collective resistance that has now collapsed (the abortive dockers' strike near the beginning) and with the cynical voice of an architect that justifies the refurbishment of cities and the accompanying abandonment of elements of their population in the name of global competition. Yet despite this totalizing drive, the film nonetheless bears witness to the loss of a universal grounds for resistance. This is signaled strongly when an exdocker turned taxi driver sings the Internationale in a range of European languages, even as the taxi drives past the dockyards. The epic spaces where the working class once was are still there. Marseille still opens onto the globe, but, having lost its epic choir, the universally translatable hymn of opposition can now only be sung ironically by a lonely voice. What remains is a fragment of a class in the confined space of a taxi. Despite its ambition and scope, the film still brings us back to the dislocated spatio-temporality of the Dardenne brothers’ La Promesse whereby intense but highly localized micro-dramas are played out against an epic backdrop that provides mute testimony to their origins but no language to speak to or oppose their present. Its political strength lies in the way it holds the fragments and the totality in tension, giving the former eloquence but also holding onto the systemic as the necessary level of explanation and, ultimately, of resistance.

\section{Conclusion}

In the early 1990s, Pierre Bourdieu and a team of radical sociologists produced a work entitled La Misère du monde. The book established a core distinction between miseries of position, which are always local and situated, and miseries of situation, which are systemic. Part of its drive was to give due recognition to often invisible miseries of position by allowing those who suffered from them to explain their social misery in detail. However, the book also 
repeatedly stressed the need to reconnect each misery of position to the systemic in order to give an adequate account of its genesis and its structural causes. Thus, while it engaged with the local miseries of the banlieue, the unemployed, the homeless, exploited women, peasants, older workers, temporary workers, ethnic minorities and young people struggling to find a place in the social landscape, it also told a bigger story of seismic social evolution. This latter embraced: the undoing of the working class and the demobilization of its union and party activists; the role of prolonged education in breaking the cycle of working class reproduction; the shift to an assistentialist State rather than one devoted to public service; a politics, marked by technocratic arrogance or self-negation, that no longer connected to social need. It was this bigger picture of the undoing of solidarities, the 'privatization' of suffering and the loss of political will that explained the current fragmentary nature of the social. The book's alternation between extended interviews with its multiple subjects and over-arching, structuring commentary is a heroic attempt to recognize yet resist that fragmentation, giving some voice back to social atoms deprived of adequate expression, but also insisting that no fragment can account adequately for itself without reference to that which lies beyond and before it. $^{10}$

Current social cinema works on the same terrain but clearly must find its own ways to make it speak productively. The clear pitfalls it faces are the politically disabling focus on the fragmentary and the local at the expense of the systemic or, worse still, the voyeuristic exploitation of a social suffering held safely at a distance. It has sought to move beyond these pitfalls in a range of ways. It has made the fragment speak to the heart of the social and preserved the memory of resistance, while reminding us that fragmentation is a process and not a state. Unable to figure the global directly, it has interpellated a nation that used to mediate the universal, reminded us of the need for systemic engagement by the assembly of 
fragments or inventively found a route back to the universal by short-circuiting neoliberalism's utopian pretensions. None of this can of course act as a substitute for an overarching language of opposition. But it can serve to remind us of the urgent need for such a thing and its necessary scope.

One might suggest, as some do, that the strand of current French fiction film that I am concerned with here has failed at both a political and an aesthetic level. ${ }^{11}$ Unable to represent capitalist globalization in its overarching scope, it might seem condemned, in a politically unproductive way, to inhabit the wreckage of past resistances and to accompany the fragmented struggles of the present. Such a judgment, I would suggest, is shortsighted in that it fails to recognize the more general collapse of an overarching leftist project. Radical opposition is now also condemned to sift through the ruins to see what can be salvaged while seeking ways to federate local mobilizations. In as far as the cinema discussed here is an active part of this broader attempt to assume, resist and move beyond a cataclysmic defeat, it is fully contemporary of its time.

\section{Filmography}

Bertucelli, Julie

Depuis qu'Otar est parti 2003

Cabrera, Dominique

Nadia et les hippopotames

2000

Chibane, Malik

Hexagone

1994

Dardenne, Jean-Pierre et Luc

Je pense à vous

La Promesse

Rosetta

1999

Doukuré, Cheik

Paris selon Moussa

2003

Dridi, Karim

Bye-Bye

1995 


$\begin{array}{llr}\text { Dupeyron, François } & \text { Inguelezi } & 2004 \\ \text { Gomis, Alain } & \text { L'Afrance } & 2002 \\ \text { Guédiguian, Robert } & \text { Marius et Jeanette } & 1997 \\ & \text { A l'Attaque } & 2000 \\ & \text { La Ville est tranquille } & 2001 \\ \text { Kassovitz, Matthieu } & \text { La Haine } & 1995 \\ \text { Masson, Laetitia } & \text { En avoir (ou pas) } & 1995 \\ \text { Poirier, Manuel } & \text { Western } & 1997 \\ \text { Siri, Florent Emilio } & \text { Une Minute de silence } & 1998 \\ \text { Tavernier, Bertrand } & \text { Ça commence aujourd'hui } & 1999 \\ \text { Zonca, Erick } & \text { La Vie rêvée des anges } & 1998\end{array}$

${ }^{1}$ I would like to thank the Arts and Humanities Research Board whose generous support made it possible to develop the broader research project of which this article is part.

${ }^{2}$ For a developed account of how Nadia et les hippopotames seeks to find a ground upon which to reconnect the fragments of the working class and to restore the severed link between a language of opposition and embodied social suffering, see Martin O’Shaughnessy, “Suffering in Silence: Bodily Politics in Post-1995 French Film,” French Cultural Studies 15, 3 (2004), pp. 219-33.

${ }^{3}$ For an account of the brothers' early video work, see René Begon, “Les années video, repères biographiques,” Revue belge du cinéma 41 (1996-7), pp. 72-82. This special number of the journal, edited by Marc-Emmanuel Mélon and Emmanuel d'Autreppe, contains an excellent series of articles on the Dardenne brothers' work up to the mid-1990s. My special thanks go to Marc-Emmanuel Mélon for his generous help when I was preparing this piece. 
${ }^{4}$ For an account of a more general turn to the melodramatic as a way to restore eloquence to social struggle deprived of a language, see Martin O’Shaughnessy, “Reprise et les nouvelles formes du cinéma politique” in Cinéma et engagement ed. Graeme Hayes and Martin O’Shaughnessy (Paris: L’Harmattan, 2005), pp. 83-98.

${ }^{5}$ For an illuminating account of the ethical dimension of La Promesse, see Marc-Emmanuel Melon, “Le visage de l’Autre ou la conscience du regard,” Revue belge du cinéma 41 (19967), pp. 91-95.

${ }^{6}$ Their comments are found on an interview that is one of the extras on the DVD of Le Fils (Arte, 2003).

${ }^{7}$ Luc Dardenne sums up the brothers' evolution by saying, “Il me semble qu'avec $L a$ Promesse, Rosetta, et puis Le Fils, on a ancré ça [le drame] dans les rapports sociaux d'aujourd'hui, mais l'enjeu entre les personages, ce n'est pas d'organiser une lutte collective, de rejoindre un combat qui existerait quelque part pour une emancipation des gens, c'est simplement refuser quelque chose à titre individuel [...] C'est devenu quelque chose qui tient plus de la morale, du rapport inter-individuel,” Multitudes 11 (2003), p. 148.

${ }^{8}$ On this, see Patricia Osganian, “D’Amerika rapports de classe à Rosetta. Sortie du naturalisme et subjectivication du réel,” Mouvements 27/28 (2003), pp. 51-7.

${ }^{9}$ Etienne Balibar, La Crainte des masses (Paris: Galilée, 1997), especially pp. 30-2.

${ }^{10}$ Pierre Bourdieu (ed.), La Misère du monde (Paris: Seuil, 1993).

${ }^{11}$ For an account of some of the criticisms levelled at the type of films discussed here, see Martin O’Shaughnessy, “Post-1995 French Cinema: Return of the Social, Return of the Political?,” Modern \& Contemporary France 11, 2 (2003), pp. 189-203. 